\title{
Analisis Emosi Akademik Sains dalam Pembelajaran Fisika dan Dampaknya terhadap Prestasi Mahasiswa
}

\author{
${ }^{1}$ Siti Fatimah, ${ }^{2}$ Umi Mahmudah, ${ }^{3}$ Moh. Muslih, ${ }^{4}$ Anik Maghfiroh \\ ${ }^{1}$ Institut Agama Islam Nahdlatul Ulama Kebumen, J1. Tentara Pelajar No.55B, Panggel, Panjer, \\ Kec. Kebumen, Kabupaten Kebumen, Jawa Tengah 54312 \\ 2,3,4 Institut Agama Islam Negeri Pekalongan, J1. Kusuma Bangsa No.9, Panjang Baru, Pekalongan \\ Utara, Kota Pekalongan, Jawa Tengah 51141 \\ Email Korespondensi: stfatimah89@gmail.com
}

\begin{tabular}{|c|c|}
\hline Article Info & Abstract \\
\hline $\begin{array}{l}\text { Article History } \\
\text { Received: } 31 \text { March } 2021 \\
\text { Revised: } 30 \text { June } 2021 \\
\text { Published: } 30 \text { June } 2021\end{array}$ & \multirow{2}{*}{$\begin{array}{l}\text { This study aims to analyze the science academic emotions of undergraduate } \\
\text { students on physics learning especially e-learning during the COVID-19 pandemic. } \\
\text { This research is a descriptive study using a qualitative approach. The subjects in } \\
\text { the study were } 119 \text { students in the second semester. Then, this study uses several } \\
\text { instruments, namely questionnaires, tests, and portfolio sheets. The results of the } \\
\text { analysis show several important findings, namely 1) undergraduate students have } \\
\text { good enough academic emotions, 2) positive science academic emotions have an } \\
\text { impact on student academic achievement, and 3) } 80.25 \% \text { of students enjoy online } \\
\text { physics learning and tend to have better levels of self-confidence }\end{array}$} \\
\hline $\begin{array}{l}\text { Keywords } \\
\text { science academic } \\
\text { emotions, e-learning, } \\
\text { physics learning, COVID- } \\
19, \text { students'achievement }\end{array}$ & \\
\hline Informasi Artikel & Abstrak \\
\hline $\begin{array}{l}\text { Sejarah Artikel } \\
\text { Diterima: } 31 \text { Maret } 2021 \\
\text { Direvisi: } 30 \text { Juni } 2021 \\
\text { Dipublikasi: } 30 \text { Juni } 2021\end{array}$ & \multirow{2}{*}{$\begin{array}{l}\text { Penelitian ini bertujuan untuk menganalisis emosi akademik sains mahasiswa } \\
\text { dalam pembelajaran fisika khususnya e-learning pada masa pandemi COVID-19. } \\
\text { Penelitian ini merupakan penelitian deskriptif dengan menggunakan pendekatan } \\
\text { kualitatif. Subjek dalam penelitian adalah mahasiswa semester dua yang berjumlah } \\
119 \text { mahasiswa. Instrumen yang digunakan berupa lembar angket, lembar tes, dan } \\
\text { lembar portofolio. Hasil analisis menunjukkan bahwa: 1) mahasiswa memiliki } \\
\text { emosi akademik sains yang cukup baik selama pembelajaran online; 2) emosi } \\
\text { akademik sains yang positif memberikan dampak yang baik pada prestasi akademik } \\
\text { mahasiswa; 3) sebanyak } 80,25 \% \text { mahasiswa dapat menikmati pembelajaran fisika } \\
\text { secara daring dan cenderung memiliki tingkat kepercayaan diri yang lebih baik. }\end{array}$} \\
\hline $\begin{array}{l}\text { Kata kunci } \\
\text { emosi akademik sains, e- } \\
\text { learning, pembelajaran } \\
\text { fisika, COVID-19, prestasi } \\
\text { belajar }\end{array}$ & \\
\hline & \\
\hline
\end{tabular}

\section{PENDAHULUAN}

E-learning menjadi sarana utama dalam pembelajaran yang digunakan pada saat pandemi Covid-19. E-learning terus mengalami perkembangan pesat. Selain memiliki kemudahan dalam mengakses materi, e-learning memiliki kelebihan yaitu tidak terbatas oleh ruang dan waktu serta mampu menghemat biaya. Terlebih pada masa pandemi ini, peserta didik tidak diperkenankan untuk belajar tatap muka di sekolah. Melalui e-learning pengguna dapat belajar darimana dan kapan saja secara mandiri. E-learning menjadi satu-satunya solusi yang terbaik sejak adanya pandemi Covid-19 agar sistem pembelajaran tetap berjalan. 
Meskipun e-learning bukan sesuatu yang baru, namun pendidik dan peserta didik yang belum terbiasa menggunakan e-learning mengalami banyak kendala, baik dari segi penyampaian materi, kegiatan keterampilan, dan juga kegiatan evaluasi. Purwanto, dkk (2020) menyebutkan bahwa terdapat beberapa kendala dalam proses belajar mengajar menggunakan sistem belajar online, yaitu penguasaan teknologi masih kurang, penambahan biaya kuota internet, adanya pekerjan tambahan bagi orang tua dalam mendampingi anak belajar, komunikasi dan sosialisasi antar siswa, guru dan orang tua menjadi berkurang dan jam kerja yang menjadi tidak terbatas bagi guru karena harus berkomunikasi dan berkoordinasi dengan orang tua, guru lain, dan kepala sekolah. Sulisworo \& Agustin (2017) juga menyebutkan bahwa kesulitan umum dalam pembelajaran ini adalah tidak mudahnya memindahkan kebiasaan yang dilakukan oleh guru di depan kelas menjadi interaksi virtual yang melibatkan berbagai komponen di dalamnya.

Kendala-kendala tersebut dapat diatasi dengan adanya persiapan yang baik dan terstruktur agar pembelajaran dapat menyenangkan dan bermakna bagi siswa serta kerjasama yang baik dari semua pihak. Melalui perancangan e-learning yang baik dapat memotivasi siswa untuk lebih terlibat dalam pembelajaran (Jethro, dkk. : 2012). Beberapa unsur penting dalam pendidikan jarak jauh berbasis web antara lain: pusat kegiatan dimana siswa dapat menambah kemampuan, membaca materi, mencari informasi; interaksi dalam grup dimana siswa dapat berinteraksi satu sama lain untuk mendiskusikan materi-materi yang diberikan dan guru dapat hadir dalam grup untuk memberikan sedikit ulasan tentang materi yang diberikan; sistem administrasi siswa dimana siswa dapat melihat kemajuan belajar selama proses berlangsung; pendalaman materi dan ujian (Sulisworo \& Agustin, 2017) .

Kurangnya kesiapan dari guru, siswa, dan orang tua menyebabkan pembelajaran daring (belajar di rumah) kurang menyenangkan. Berdasarkan hasil survey yang dilakukan olehKomisi Perlindungan Anak Indonesia (KPAI) pembelajaran jarak jauh (PJJ) yang dilakukan selama pandemi Covid-19 masih kurang efektif. Sebanyak 77,8\% responden menyatakan terlalu banyak tugas yang menumpuk dan $37,1 \%$ mengeluhkan waktu pengerjaan tugas yang sempit sehingga membuat siswa kurang istirahat dan kelelahan. Dampak yang ditimbulkan dari adanya pembelajaran online yang tidak terstruktur mengakibatkan menurunnya minat, motivasi, dan mental siswa dalam proses belajar mengajar. Hasanah, dkk (2020) menyebutkan bahwa pembelajaran online pada masa pandemi dapat menyebabkan kecemasan bagi siswa. Hasil penelitian Maia, dkk (2020) menunjukkan bahwa para siswa yang dievaluasi selama periode pandemi menunjukkan tingkat kecemasan, depresi, dan stres yang jauh lebih tinggi, 
dibandingkan dengan para siswa pada masa-masa normal. Hasil menunjukkan bahwa pandemi memiliki efek psikologis negatif pada siswa.

Tingkat kecemasan dapat mempengaruhi prestasi siswa, karena kecemasan mampu menghasilkan kebingungan dan menurunnya kemampuan memusatkan perhatian serta daya ingat (Kaplan \& Saddock, 2005). Hasil temuan yang dilakukan oleh Livana, dkk (2020) menunjukkan bahwa jumlah tugas yang terlalu banyak dalam pembelajaran online pada saat pandemi Covid19 menjadi faktor utama yang menyebabkan stress siswa. Masalah-masalah tentang adanya dampak pembelajaran online jika tidak segera diatasi akan mengakibatkan penurunan kualitas siswa dan menimbulkan masalah psikologis yang lebih besar lagi. Hasanah, dkk (2020) menyebutkan bahwa gangguan seperti depresi dapat menyebabkan manifestasi psikomotor berupa keadaan gairah, semangat, aktivitas serta produktivitas kerja yang bertendensi menurun, konsentrasi dan daya pikir melambat.

Berdasarkan hasil studi pendahuluan yang dilakukan ke mahasiswa dalam pembelajaran fisika, mayoritas responden dideteksi mengalami gejala-gejala kesehatan mental yang menurun dan memiliki tingkat kecemasan yang tinggi. Mayoritas responden (sekitar 93.40\%) menyatakan memiliki kekhawatiran yang berlebihan, sebanyak responden yang menyatakan setuju $(41,90 \%)$ dan sangat setuju $(43,33 \%)$ menyatakan merasa tertekan adanya tugas-tugas sekolah pada masa COVID-19. Hasil juga mengindikasikan bahwa mayoritas responden $(92,38 \%)$ tidak memiliki waktu istirahat yang cukup, tidak bisa istirahat secara tenang dan nyaman disebabkan banyaknya tugas-tugas sekolah yang harus diselesaikan dalam waktu yang singkat. Dan perasaan bahagia yang dirasakan oleh mahasiswa cenderung tetap yaitu hanya sekitar 30\% bahkan dalam satu pertemuan terdapat penurunan perasaaan bahagia. Dijelaskan dalam Otaghi, dkk (2019) bahwa kebahagiaan mampu meningkatkan prestasi akademik siswa. Siswa yang memiliki kebahagiaan dan kesehatan mental yang baik akan mampu meningkatkan prestasi dan performance akademik siswa. Kamarudin, dkk (2009) menyebutkan bahwa stress dapat mempengaruhi proses belajar dan akademik prestasi siswa. Disebutkan juga dalam Ghatol (2017) bahwa stress merupakan faktor penting dalam mempengaruhi prestasi dan performance akademik siswa.

Berdasarkan permasalahan-permalahan tersebut, perlu adanya kajian tentang pentingnya memahami emosi akademik. Sunawan, dkk (2017) menyebutkan bahwa beban kognitif perlu dikaitkan dengan faktor non-kognitif seperti emosi akademik. Emosi akademik adalah emosi yang muncul selama siswa mengikuti proses pembelajaran (Sunawan, dkk: 2017). Disebutkan juga dalam Pekrun, dkk (2011) pengaturan akademis penuh dengan emosi akademik seperti kenikmatan belajar, harapan, kesombongan, kemarahan, kecemasan, rasa malu, kehilangan 
harapan, atau kebosanan. Penelitian ini akan menggambarkan emosi akademik mahasiswa dalam pembelajaran fisika melalui pembelajaran online dan dampaknya terhadap prestasi akademik mahasiswa.

\section{METODE}

Penelitian ini merupakan penelitian kualitatif dengan jumlah responden sebanyak 119 mahasiswa semester 2 yang menjalani proses pembelajaran daring selama pandemi Covid-19 . Penelitian ini dilakukan selama tiga bulan dan sebanyak 7 kali tatap muka. Instrumen yang digunakan berupa lembar angket, lembar portofolio, dan lembar tes. Instrumen pengukuran emosi akademik sains menggunakan skala Achievement Emotions Questionnaire (AEQ) yang diadaptasi dari Pekrun, Goetz, Frenzel, Barchfeld \& Perry (2011) yang terdiri dari 24 item pertanyaan dengan tiga indikator yang diukur yaitu emosi kelas (Class-related emotions), emosi pembelajaran (Learning-related emotions), dan emosi evaluasi/tes (Test emotions). Indikator emosi kelas dan pembelajaran menilai kebosanan, keputusasaan, kemarahan, kecemasan, kenikmatan, kebanggaan, harapan, dan rasa malu. Sedangkan komponen emosi tes juga menilai hal yang sama seperti emosi kelas dan pembelajaran, namun kebosanan diganti dengan kelegaan. Untuk ketiga komponen emosi tersebut, item diurutkan dalam tigahal yaitu sebelum (before), selama (during), dan setelah (after) melakukan kelas/pembelajaran dan evaluasi/tes. Instrumen AEQ yang dibuat menggunakan skala likert dengan empat alternatif pilihan jawaban (Sangat Setuju, Setuju, Tidak Setuju, Sangat Tidak Setuju). Lembar tes berupa soal uraian tentang analisis konsep usaha dan energi serta gerak. Sedangkan protofolio terdiri dari laporan praktikum dan tugas-tugas yang lain.

Teknik uji keabsahan penelitian ini dilakukan dengan teknik triangulasi yang kemudian dianalisis menggunakan model yang dikembangkan oleh Miles and Huberman yaitu data collection, data reduction, data display, and conclusions. Hasil analisis data dihitung dengan menggunakan persamaan di bawah ini (Widoyoko, 2016).

$$
M=\frac{A}{B} \times 100 \%
$$

Keterangan:

$\mathrm{M}=$ Persentase keberhasilan pelatihanA

$=$ Skor hasil penelitian

$\mathrm{B}=$ Skor tertinggi ideal

Sedangkan kriteria emosi akademik mahasiswa dapat dilihat pada tabel 1 (Widoyoko, 2016). 
Tabel 1. Kriteria Tingkat Emosi Akademik Sains

\begin{tabular}{cc}
\hline Rentang Persentase (\%) & Kriteria Emosi Akademik \\
\hline$\geq 90$ & Sangat Tinggi \\
$80-89$ & Tinggi \\
$70-79$ & Cukup \\
$60-69$ & Kurang \\
$<60$ & Sangat Kurang \\
\hline
\end{tabular}

\section{HASIL DAN PEMBAHASAN}

Penelitian ini menggunakan sampel 119 mahasiswa dengan deskripsi sebagai berikut.

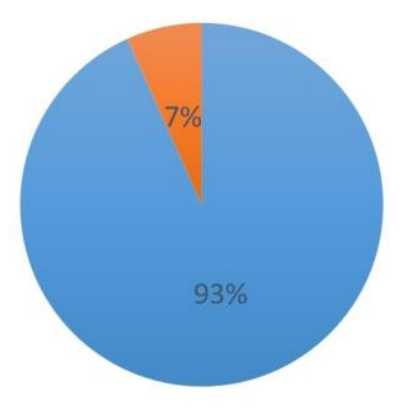

Perempuan ㄴ. Laki-Laki

Gambar 1. Deskripsi Responden

Berdasarkan gambar 1, responden perempuan sebanyak 93\% dan responden laki-lakisebanyak 7\%. Sedangkan hasil analisis data penelitian dapat dilihat pada table 2

Tabel 2. Ringkasan hasil emosi akademik

\begin{tabular}{|c|c|c|c|c|c|}
\hline \multirow{3}{*}{ No } & \multirow{3}{*}{ Emosi } & \multicolumn{3}{|c|}{ Aspen } & \multirow{3}{*}{$\begin{array}{l}\text { Rata-Rata } \\
\text { Persentase }\end{array}$} \\
\hline & & \multirow{2}{*}{$\begin{array}{c}\text { Class-related } \\
\text { emotions }\end{array}$} & \multirow{2}{*}{$\begin{array}{c}\text { Learning-related } \\
\text { emotions }\end{array}$} & \multirow{2}{*}{$\begin{array}{c}\text { Test } \\
\text { emotions }\end{array}$} & \\
\hline & & & & & \\
\hline & Negatif & & & & \\
\hline 1 & Kebosanan & $67,01 \%$ & $70,58 \%$ & - & $68,79 \%$ \\
\hline 2 & keputusasaan & $75 \%$ & $72,89 \%$ & $76,68 \%$ & $74,85 \%$ \\
\hline 3 & kemarahan & $75,84 \%$ & $74,15 \%$ & $74,78 \%$ & $74,92 \%$ \\
\hline 4 & kecemasan & $64,91 \%$ & $62,39 \%$ & $57,56 \%$ & $61,62 \%$ \\
\hline \multirow[t]{3}{*}{5} & rasa malu & $67,43 \%$ & $61,55 \%$ & $63,65 \%$ & $64,21 \%$ \\
\hline & & Jumlah & & & $68,87 \%$ \\
\hline & Positif & & & & \\
\hline 6 & kebanggaan & $75,63 \%$ & $73,73 \%$ & $74,15 \%$ & $74,50 \%$ \\
\hline 7 & harapan & $73,10 \%$ & $75,21 \%$ & $74,78 \%$ & $74,36 \%$ \\
\hline 8 & kelegaan & - & - & $84,87 \%$ & $84,87 \%$ \\
\hline \multirow[t]{2}{*}{9} & kenikmatan & $71,21 \%$ & $80,25 \%$ & $70,58 \%$ & $74,01 \%$ \\
\hline & & Jumlah & & & $76,93 \%$ \\
\hline
\end{tabular}

Berdasarkan tabel 2, dapat dijelaskan bahwa mahasiswa memiliki emosi akademik yangcukup baik. Terlihat pada hasil rata-rata persentase bahwa pada emosi akademik yang positif 
sebesar 76,93\% menunjukkan kategori cukup tinggi, sedangkan emosi akademik yang negatif sebesar $68,87 \%$ menunjukkan kategori rendah. Berdasarkan hasil deskripsi, mayoritas mahasiswa memiliki emosi akademik yang positif. Hanya satu mahasiswa yang memiliki emosi akademik yang negatif. Artinya mahasiswa memiliki emosi akademik positif yang baik dalam pembelajaran fisika secara daring. Mahasiswa yang memiliki emosi akademik positif akan lebih menikmati pembelajaran daripada mahasiswa yang memiliki emosi akademik negatif. Terlihat sebanyak 80,25\% mahasiswa dapat menikmati dan memiliki kepercayaan diri yang baik selama pembelajaran fisika secara daring. Emosi akademik mahasiswa selama pembelajaran akan mempengaruhi kegiatan belajar mengajar dan pemahaman pada materi.

Pekrun, dkk (2011) menyebutkan bahwa emosi akademik sangat mempengaruhi pembelajaran dan kinerja akademik peserta didik. Emosi akademik mempengaruhi motivasi instrinsik dan ekstrinsik peserta didik. Emosi akademik yang positif akan meningkatkan motivasi peserta didik, sedangkan emosi akademik yang negatif akan mengurangi motivasi dan pemrosesan informasi yang cermat sehingga hal tersebut akan berdampak pada pembelajaran dan kinerja akademik peserta didik. Peserta didik yang memiliki emosi akademik positif akan memiliki motivasi yang tinggi sehingga dapat berdampak pada prestasi akademik. Berdasarkan hasil tes dan portofolio, mahasiswa menyelesaikan tugas-tugas dengan sangat baik dan sesuai dengan instruksi. Rata-rata nilai tes akhir didapatkan 86,19. Hasil ini menunjukkan bahwa mahasiswa memiliki nilai rata-rata yang baik meskipun pembelajaran fisika dilakukan secara daring. Berdasarkan hasil analisis, mahasiswa memiliki motivasi sains yang baik juga dalam pembelajaran daring yaitu sebanyak $99,62 \%$ mahasiswa memiliki motivasi sains yang tinggi sedangkan hanya $0,38 \%$ yang memiliki motivasi sains rendah. Tingginya motivasi sains yang dimiliki oleh mahasiswa merupakan dampak dari emosi akademik positif yang dimiliki oleh mahasiswa. Ouano (2011) menyebutkan bahwa emosi akademik berkorelasi positif terhadap motivasi baik motivasi instrinsik maupun motivasi ekstrinsik. Peserta didik yang memiliki emosi akademik positif akan memberikan dampak langsung terhadap peningkatan motivasi sehingga akan mempengaruhi pembelajaran dan prestasi akademik peserta didik.

\section{KESIMPULAN}

Berdasarkan hasil analisis dapat disimpulkan bahwa mahasiswa memiliki emosiakademik sains yang cukup baik. Emosi akademik yang positif akan berdampak pada motivasi mahasiswa sehingga berpengaruh terhadap prestasi akademik mahasiswa. Sebanyak 
$80,25 \%$ mahasiswa dapat menikmati pembelajaran fisika secara daring dan cenderung memiliki tingkat kepercayaan diri yang lebih baik.

Penelitian ini perlu ditindak lanjuti tentang faktor-faktor yang mempengaruhi prestasi akademik mahasiswa selama pembelajaran fisika via daring selain emosi akademik dan motivasi peserta didik.

\section{SARAN}

Pengembangan LKPD proses yang dilakukan baru sampai tahap development, bagi peneliti dibidang yang sama diharapkan kedepannya mampu mengembangkan hingga tahap implementation sehingga terlihat gambaran maupun sebaran kemampuan berpikir peserta didik dengan menggunakan LKPD proses yang telah dikembangkan. Bagi pendidik perlu memperhatikan karakter dan kemampuan awal berpikir kritis masing-masing peserta didik sehingga memiliki rancangan mengembangkan kemampuan berpikir kritis sesuai kemampuan awal yang dimiliki. Bagi peserta didik sangat penting untuk mengikuti alur pembelajaran karena didalamnya terdapat serangkairan sintaks dan indikator yang harus dikembangkan.

\section{DAFTAR PUSTAKA}

Ghatol, S.D. (2017). Academic Stress among Higher Secondary School Students: A Review. International Journal of Advanced Research in Education \& Technology (IJARET). Vol 4 (1): $38-41$.

Hasanah, U., Ludiana, Immawati, \& Livana, P.H. (2020). Gambaran Psikologis Mahasiswa Dalam Proses Pembelajaran Selama Pandemi Covid-19. Jurnal Keperawatan Jiwa. Vol 8 (3): 299306.

Jethro, O.O., Grace, A.M., \& Thomas, A.K. (2012). E-Learning and Its Effects on Teaching and Learning in a Global Age. International Journal of Academic Research in Business and Social Sciences. Vol 2 (1): 203-210.

Kamarudin, R., Chong, S.C., Norzaidi, M.D., \& Mohamed, I.S. (2017). The Impact of Perceived Stress and Stress Factors on Academic Performance of Pre-Diploma Science Students: A Malaysian Study. International Journal of Scientific Research in Education. Vol. 2(1), 13-26.

Kaplan, H.I \& Saddock, B.J. (2005). Sinopsis Psikiatri. 8th ed. Jakarta: Bina Rupa Aksara. KPAI. (2020). "Ada 246 Aduan di KPAI soal Belajar Daring, Siswa Keluhkan Tugas

Menumpuk-Kuota".

Diakses

dalam

https://www.kpai.go.id/berita/ada-246-aduan-di-kpai-soal-belajar-daring-siswa-keluhkantugas-menumpuk-kuota.

Livana, P.H., Mubin, M. F., \& Basthomi, Y. (2020). " Learning Task" Attributable to Students' Stres During the Pandemic Covid-19. Jurnal Ilmu Keperawatan Jiwa. Vol 3(2):203-208. http://dx.doi.org/10.32584/jikj.v3i2.590.

Maia, Berta Rodrigues And Dias, Paulo César. (2020). Anxiety, depression and stres in university students: the impact of COVID-19. Estud. psicol. (Campinas) [online]. vol.37. http://dx.doi.org/10.1590/1982- 0275202037e200067.

Sulisworo, D., \& Agustin, S.P. (2017). Dampak Pembelajaran E-Learning Terhadap Motivasi Pada Pembelajaran Fisika Di Sekolah Kejuruan. Berkala Fisika Indonesia. Vol 9 (1): 1-7. 
Sunawan, Yani, S.Y.A., Kencana, T.I., Anna, C.T., Mulawarman, \& Sofyan, A. (2017). Dampak Efikasi Diri terhadap Beban Kognitif dalam Pembelajaran Matematika dengan Emosi Akademik sebagai Mediator. Jurnal Psikologi. Vol 44 (1): 28-38.

Otaghi, M., Sayehmiri, K., Valizadeh, R., \& Tavan, H. (2019). Correlation Between Happiness and Academic Achievement in Iranian Students: A Meta-Analysis Letter. Shiraz E-Med J. Online ahead of Print ; 21(3):e94277. doi: 10.5812/semj.94277.

Ouano, J. (2011). Motivational Antecedents of Academic Emotions in Filipino College Students. The Asia-Pacific Education Researcher. Vol 20 (1): 127-132.

Pekrun, R., Goetz, T., Frenzel, A.C., Barchfeld, P., \& Perry, R. P. (2011). Measuring Emotions in Students' Learning and Performance: The Achievement Emotions Questionnaire (AEQ). Contemporary Educational Psychology. Vol 36: 36-48.

Purwanto, A., Pramono, R., Asbari, M., Santoso, P. B., Wijayanti, L. M., Hyun, C. C., Putri, R. S. (2020). Studi Eksploratif Dampak Pandemi COVID-19 Terhadap Proses Pembelajaran Online di Sekolah Dasar. Journal of Education, Psychology, and Counseling. Vol 2 (1): 1-12.

Widoyoko, E. P. (2016). Penilaian Hasil Pembelajaran di Sekolah. Yogyakarta: Pustaka Pelajar. 